\title{
特集【論説】 大規模集客施設の郊外立地規制について考える
}

\section{福島県における大規模商業施設の立地動向と都市計画の取組み}

The Present Situation of City Planning in Fukushima Prefecture

Toichi ENDO : Fukushima Prefecture

遠藤 東一*

The present situation of city planning in Fukushima prefecture is explained. Then author discusses the problems of the large--scale commercial facilities, and proposes the opinion about the revised city planning law and also reports the tougher regulation, the urbanization policies and the future city planning policy of Fukushima prefecture--scale.

keywords : city planning in Fukushima prefecture, large commercial facilities, declining of urban center, the tougher regulation, the future city planning policy

福島県の都市計画，大規模小売店舗，中心市街地空洞化，規制型条例，将来に向けた都市政策

\section{福島県の都市計画区域図}

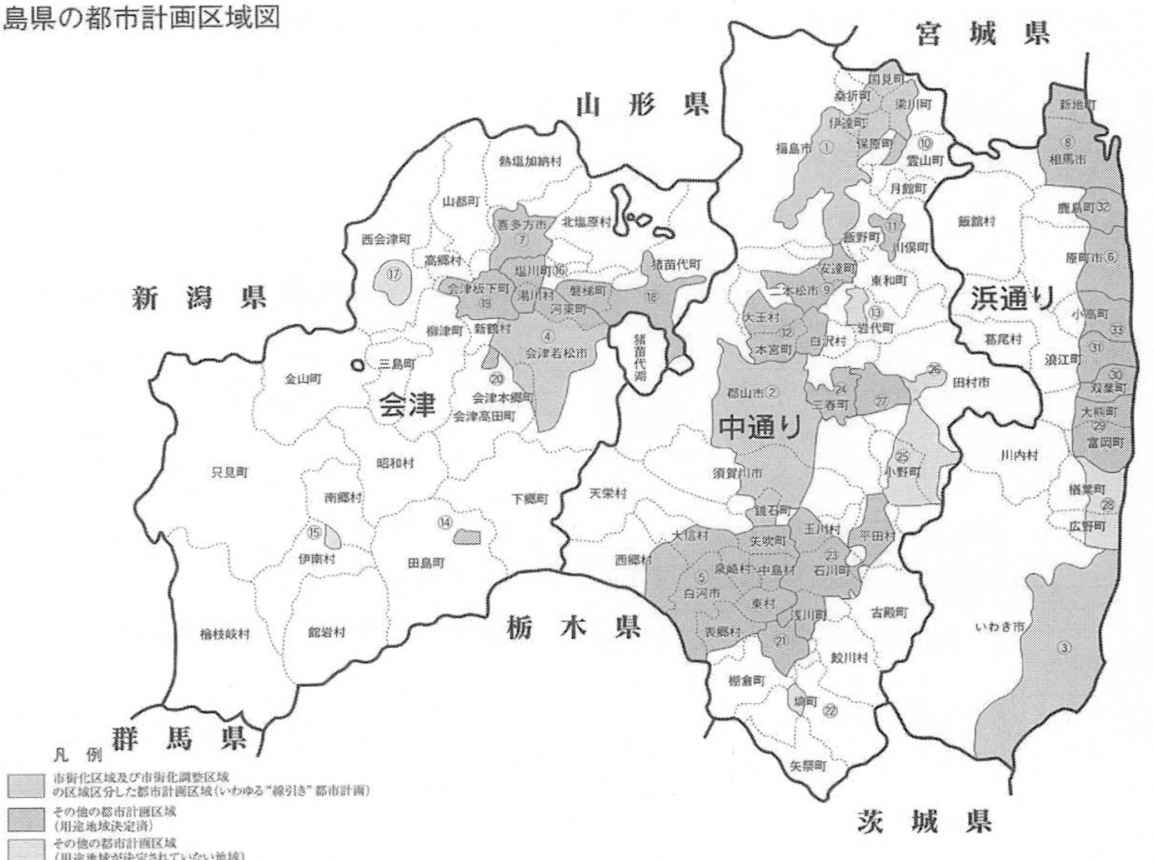

図-1 


\section{はじめに}

福島県では，まちづくり三法の見直しに関連し て新しい時代に対応できるまちづくりに取り組ん でいる。本稿では, 県内の都市の現状と課題, 大 規模集客施設の立地の動向とその影響等を報告す るとともに，県内の都市の課題を踏まえながら改 正都市計画法の効果と問題を検討している。更に, 商業まちづくり推進条例等のまちづくりに関する 県独自の取組み, 改正都市計画法の適切な運用を 図りながら, 将来のまちづくりのための都市計画 の運用指針の策定等について報告する。

\section{1 福島県の都市計画の現状}

福島県は約138百 $\mathrm{km}^{2}$ の広大な県土面積に，61の市 町村があるが，このうち市街化区域及び市街化調 整区域を定めた，いわゆる線引き都市計画区域は 福島市等の県北都市計画区域など，4 都市計画区 域の10市町，この他の非線引き都市計画区域が29 区域の35市町村で構成されており，これらの33都 市計画区域は県土の約 $25 \%$ 占めているが，この 区域に県人口の約 $87 \%$ が集中している。

県人口は平成 9 年の約 213 万千人をピークに その後減少傾向にあり, 平成17年度の国勢調査で は 210 万人下回っており, 高齢化率は $22 \%$ 超え て, 少子超高齢化が進行している。また, 都市計 画区域の人口は県北, 県中都市計画区域では伸び 率は鈍化しているものの依然として増加傾向にあ るが，その他の区域では平成 7 年以降は減少傾向 を示しており，都市部においても全県同様の傾向 を示している。

県内の主要な都市では, 昭和 40 年代の高度成長 期以降, 都市内人口の増加や過密な都市問題等に 対応する政策のもとに，市街化区域の拡大と都市 施設の整備を推進して, 郊外部における幹線道路 のバイパスの整備, 工場・住宅等の団地の造成が 行われ，大学や公立病院等の公共施設の郊外への
移転が進められた。また，市民のライフスタイル の変化，モータリゼーションの更なる進展により， 大型店等の大規模集客施設は広い敷地と駐車場を 求めて, 郊外の幹線道路沿線に立地, 集積が進行 して, 都市を取り巻く情勢が変わり, 現在もこの 傾向は続いている。これらの結果，都市内の人口， 産業が郊外流出し, 平成以降, 主要都市の駅前等 の中心市街地では, 県外資本のデパートの撤退, 地元老舗デパートの閉店などが続き, 空き店舗, 駐車場の増加により商店街の衰退と空洞化が深刻 化し, 街なかの居住環境, 伝統文化・コミュニティ の維持や景観, 防犯などの問題が大きな課題と なっている。都市は中心市街地と郊外部という二 極の形態となり, 郊外部の新たな社会資本の整備 とともに街中の施設の管理が必要であり，それぞ れの社会資本の整備, 管理の財政負担の増大も新 たな問題となっている。

かつて，大規模に開発された郊外のニュータウ ンにマイホームを求めた市民の年齢層は, 一定層 に限られていたため, 人口構成は極めて偏ったも のであり，子供たちは成長とともに県外に転出し， 郊外の学校には空き教室が残り, 人口減少ととも に中高年層の団地に変わりつつある。

最近は, 郊外の団地から中心市街地のマンショ ンへ転居する熟年世代が増えていることからマン ション建設が伸びており, 商業施設等を併設する 複合的住宅なども整備されている。県庁所在地の 福島市では，かつて減少する一方だった都心人口 が平成14年以降増加に転じ，郡山市では中心市街 地における来街者数の増加等, 市民の都心回帰と いう傾向も見られている。

県は平成16年に,「自然と共生する環境負荷の小 さい美しいまちづくり」の理念に基づき, 都市計 画区域マスタープランを策定して, 今後 20 年後の 将来のまちづくりビジョンを示しており，このマ スタープランに即して市町村は都市マスタープラ ンを策定して，住民に身近なまちづくりを進めて 
いる。県としては，7つの生活圈の地域特性を生 かした「ひと，こころ，くらし」に軸足を置いた 都市政策を推進するための 3 つの基本理念に基づ いた，「個性と魅力ある美しいまちづくり」など 5 つの基本目標を目指して県民が豊かで活き活きと 暮せる市町村のまちづくりを支援している。

\section{2 福島県の大規模集客施設の立地動向}

今回の都市計画法, 建築基準法改正によって, 規制される大規模集客施設（大型小売店, 劇場, 店舗，飲食店等）について，顕著なものは大規模 小売店舗であり，この立地に誘引されて飲食店・ サービス業が集積する傾向が認められる。

県内の線引き都市計画区域では都市計画法によ り開発を規制しているので, 商業地域等の大規模 小売店が立地可能な市街化区域には集積している が，市街化調整区域には原則立地できない。しか し, 最近の傾向は, 市街化区域でも郊外部の幹線 道路の沿線地域及び遊休地・未分譲となっている 工場用地等での立地傾向が目立っており, モー夕 リゼーションの進展と相まって, 地価の高い中心 市街地内の商業地域への立地は限られている。

その他の非線引き都市計画区域では, 都市計画 法で開発の規制ができないため, 農業振興地域の 整備に関する法と農地法等の手続きにより立地は 可能である。このため, 特に大規模な小売店舗 （以下「大型店」という。）は，中心都市に隣接す る非線引き都市計画区域内の用途地域が定められ ていない，いわゆる白地地域に立地する傾向があ る。これらの大型店は, モータリゼーションを活 用して, 立地する自治体の商圈を遥かに超える規 模の店舗面積を持ち, 大きな商圈を手に入れて企 業活動をしている。最近の傾向としては, 従来に
おいて大型店の立地が全く想定されなかった主要 都市の間に位置する, 人口が数千人規模の自治体 の広大な優良農地を転用して立地する傾向があり, 現在も 1 万数千 $\mathrm{m}^{2}$ から 3 万 $\mathrm{m}^{2}$ を超える店舗面積 の大型店の出店計画が進行しており,この立地動 向に対して法改正以前の都市計画法での対応には 限界がある。

県内には, 約400の大型店 (店舗面積 $1,000 \mathrm{~m}^{2}$ 超) があるが，郡山市等の都市部に集積しており，立 地傾向としては, 約 6 割が 3 千 $\mathrm{m}^{2}$ 以下で, 1 万 $\mathrm{m}^{2}$ を超える店舗は 30 件，約 $7 \%$ となている。

大規模小売店舗立地法が施行された平成12年以 降に届出のあった大型店は55件，全て都市計画区 域内の立地であり, 都市化が進んでいる線引き都 市計画区域の市街化区域に 7 割，残り 3 割は非線 引き都市計画区域に立地している。用途地域では, 準工業地域が 13 件の約 $23 \%$, 工業地域が 11 件の約 $20 \%$ と業系で 4 割を超える。また第一種住居地 域も 2 割弱であるのに対して, 商業地域は 2 件, 近隣商業地域は 5 件と商業系では約 $13 \%$ あ゙あ。 非線引き都市計画区域の白地の立地は 6 件, 約 1 割であるが, 店埔面積は 1 万 6 千 $\mathrm{m}^{2}$ の店舗を筆頭 にいずれも大規模な店舗である。土地利用種別で は，農地が 24 件の $43 \%$ ，工場等の跡地が 13 件 $23 \%$ となっている。中心市街地での立地は $7 \%$ 件 で他は市街地外縁や郊外での立地である。改正都 市計画法では, 1 万 $\mathrm{m}^{2}$ 超の大型店は商業地域等 3 用途地域以外では制限されるため, 改正法施行後 は56店の内, 工業地域, 白地地域に立地している 8 店舖は建築基準法の既存不適格建築物となり, 同様の立地が制限されることになる。また，立地 可能となる用途地域内での立地は 2 件に過ぎない 状況である。 
表-1 大規模小売店舖の立地動向（平成12年以降）

\begin{tabular}{|c|c|c|c|}
\hline 都市計画区域 & 線引き & 非線引 & 計 \\
\hline 第二種中高層住居地域 & 1 & 0 & 1 \\
\hline 第一種住居地域 & 9 & 2 & 11 \\
\hline 第二種住居地域 & 1 & 2 & 3 \\
\hline 準住居地域 & 1 & 2 & 3 \\
\hline 近隣商業地域 & 4 & 1 & 5 \\
\hline 商業地域 & 2 & 0 & 2 \\
\hline 準工業地域 & 9 & 4 & 13 \\
\hline 工業地域 & 10 & 1 & 11 \\
\hline 用途指定の無い地域※ & - & 6 & 6 \\
\hline 計 & 37 & 18 & 55 \\
\hline
\end{tabular}

・用途地域は店舗の主要な部分が占めるもの

※：いわゆる非線引き白地地域

平成 9 年頃に県北都市計画区域の伊達市（旧伊 達町）の市街化調整区域内の農地において, 大規 模SCの出店が計画された事例の動向は全国的に 注目されている。伊達町は出店計画を受けて, 県 に市街化区域編入を要望したが, 近隣の 4 町の議 会は地域経済，住民生活，まちづくりへの影響か ら市街化区域の編入をしないことを求める旨の意 見書を議決し県に提出した。県はこれらの状況を 判断して, 市街化区域の編入を行わなかったため, 現在も市街化調整区域のままで, 開発許可はされ ていない。

その後, 大規模SCは計画規模を縮小して出店す る計画を進めており, 誘致を推進する団体は平成 18年度になり住民に署名活動を呼びかけながら， 市街化区域編入を要望しているが，これに対し周 辺の商工団体等は反対の活動を行っており，この 出店計画の動きは国土交通委員会でも論議され, 報道機関，各自治体からも関心が寄せられている。

県としては, 現在, 出店計画地域の周辺の広域 的な合意形成ができていないこと, 都市計画区域 マスタープランとの整合性などの理由から市街化
区域の編入を行わない方針を堅持している。

\section{3 改正都市計画法等に対する意見等}

\section{（1）大規模集客施設の立地の規制}

いわゆる「まちづくり三法」は平成10年に制定 され, 都市計画法も改正されて, 商業調整をしな い大規模小売店舗立地法に対して, 都市計画の ゾーニングで対応する制度とされたが，この制度 は活用されないまま, 郊外部の大型店の立地には 歯止めが効かない状況は既に紹介したとおりであ る。

事業者は消費者を確保しやすく地価の安価な郊 外部の幹線道路沿いの農地を求め, 農家も営農よ り遥かに収入が得られる農地の借地に同意して, 広い駐車場を持つ大型店は, 都市計画法の制限を 受けずに農地法の手続きにより立地できた。

市町村は, 税収と雇用の確保を求めて, 積極的 に大型店を誘致したのであって, 大型店の立地を 規制する都市計画制度は，消費者である住民，市 町村, 事業者の意向に反するもので, 活用はされ なかったのである。

しかし, この結果は, 中心市街地の衰退ととも に，立地する自治体と周辺自治体との間に軋軪を 生じさせている。

改正都市計画法により, 新たな大規模集客施設 の立地が制限されて, 商業地域等の誘導すべき地 域に限定して立地させることは, 都市の郊外化に 対する抑制効果となり, 持続可能なコンパクトな まちづくりの推進に寄与するものと考える。

また, 大型店を立地させたい市町村は, 用途地 域の見直しや開発整備促進区を指定することがで きるが, 都市計画の手続きにおいて, 知事の同意 に関係市町村の意見が反映されて, 広域的に調整 を図る点では評価できるが, 依然として郊外の幹 線道路沿いやIC周辺は近隣商業地域や準工業地 域に指定されていることが多く, 今後とも郊外部 での大型店の出店が可能であり, 効果を疑問視す 


\section{る見方もある。}

また，既に大型店の立地が充足状況で過剩な立 地とも言われており，商業統計において県内の小 売業について平成14年，16年を比較すると販売額 では約 $3 \%$ 減少，事業所数では約 $5 \%$ 減少してい るにも拘らず，店舗面積は地域差があるものの全 県では逆に約 $2 \%$ 増加している。果たして, 今回 の改正時期が適切であったのか疑問を呈する意見 もある。

都市郊外の幹線道路周辺の拠点では，既に大規 模集客施設の集積地として機能しており, 今後と も継続して営業ができることから，利用する市民 のライフスタイル上，大きな影響はないが，今後 は立地可能な地域が制限されるため，既存店舗に とっては出店攻勢という淘汰から息を入れること にもなる。

これに対して，日本チェーンストア協会等は， 我が国の人口当たりの大型SC数はアメリカに比 べるとまだ少なく,国内商業市場には100以上の大 型商業施設の開発余地があると想定しており，今 後の出店戦略上，大きな影響を受けることに対し 強く反発しており，「時代に逆行する法改正であ る。と批判している。また，大型店を誘致して， 税収，雇用確保により，地域興しを図ろうとする 市町村と, 誘致推進の遊休農地を持つ農家などは 土地の資産価値の制限に対し反対の意向であり, 郊外の大型店等を日常的に利用している消費者も 賛同はしていない。改正法の施行は 1 年半以内に 3 段階において施行されることになっているが， その間も大型店の立地は進んでおり，いわゆる駆 け込み的出店も想定される。また，規制される大 型店は 1 万 $\mathrm{m}^{2}$ 超に限定されるため, 規制に適応す る出店戦略に方針転換しようとする企業も出現し ている。

まちづくり三法として, 中心市街地活性化法も 改正されたが，大規模集客施設の立地規制により 中心市街地が活性化するものではなく，中心市街
地のあり方は「選択と集中」の観点から, 都市全 体，強いては行政区域全体の中で検討すべきもの であり，市民の合意のもとに進めていく必要があ る。

\section{(2) 準都市計画区域}

県内には現在，準都市計画区域の指定はない。 都市計画区域外は基本的に中山間地であり，複雑 な山地地形も多く, 今後とも開発動向の顕在化は 想定されないため当面指定をする状況にはないが, 将来の大規模開発等の動きも見据え，都市計画法 の改正を契機として，指定検討をすることになる と考える。

\section{（3）開発許可制度の見直し}

市街化調整区域内の大規模開発が規制され，学 校，病院等の公共施設の立地をする際に開発許可 が必要になることは，大規模集客施設の立地制限 とともに，都市機能の郊外流出の歯止めとなり， 将来のまちづくりビジョンの実現に効果的制度と 考える。

一方, 急激な人口減少 - 超高齢社会の進展や営 農環境の変化などを受け，特に市街化調整区域に おける旧役場があった集落や旧街道沿いにある既 存集落等の地域社会（コミュニティ）が著しく衰 退しつつある。このため本県では，コミュニティ の維持再生と美しく活力のある田園地域の形成を 図る観点から，一定の社会基盤が整っている集落 において自己用住宅の新築等を許可する，いわゆ る3483条例の制定を進めている。

\section{4 福島県独自のまちづくりの取組み}

\section{（1）福島県商業まちづくり推進条例}

県では，持続可能な歩いて暮せるまちづくりの 実現を図るために，特定小売商業施設（店舗面積 が 6 千 $\mathrm{m}^{2}$ 以上の小売店舗）の立地について，県が 広域のまちづくりの見地から調整するとともに， 特定小売商業施設の事業者の地域貢献活動を位置 付けること等を規定する県の条例を，平成 17 年 10 
月18日に制定し，県と市町村等の緊密な連携と住 民等との協働をもとに運用することとしており， 県は市町村の商業まちづくりの推進の支援に配慮 している。

特定小売商業施設を立地しようとする事業者は, 出店前に県に届出を行い, 県は届出内容について 住民・関係市町村，商業まちづくり審議会の意見 を聴き，この結果を踏まえて，立地の適否を審査 して事業者に意見を通知することとしている。な お，特定小売商業施設の立地の適否に関する考え 方は，商業まちづくり基本方針に示されている。 さらに，市町村は，この基本方針を踏まえて，そ れぞれの小売商業施設の配置方針を示す商業まち づくり基本構想を策定することを位置付けている。 この条例は本年10月 1 日から施行される。

\section{(2)「新しいふくしまのまちづくり」の取組み}

県は,「車」中心から「人」中心のまちづくりを 推進するために, 新しい時代にふさわしいまちづ くりのあり方等を検討するために, 庁内でまちづ くりプロジェクトチーム内に専門のチームを設置 するとともに，まちづくりビジョンの策定にあた り, 専門的見地から調査・検討するために, 学識 経験者で構成する検討委員会を設置しており, 本 年秋には郡山市を皮切りに順次, 県内の主要都市 の中心市街地において「歩いて暮せる社会実験」 を実施し，車両の乗り入れを制限する区域を設定 して, オープンカフェやバザーなどのイベントを 開催しながら, 街なかの賑わい創出に関する実験 を行い, まちづくりビジョンを検討することとし ている。

\section{（3）「新しい時代に対応した都市政策」の策定}

県は, 人口減少等の今後の社会経済情勢を踏ま え, 本県の地域の実情や特性に応じた独自の都市 計画制度の運用指針「新しい時代に対応した都市 政策」を策定するため，本年 5 月に県都市計画審
議会内に都市政策・地域政策等の学識経験者等で 構成する標記の専門小委員会を設置して, 平成19 年を目途に運用方針を策定することとしている。

具体には都市と田園環境の共生等のあり方, 新 たな土地利用・交通施策，準都市計画区域も含め た都市計画区域等のあり方，改正都市計画法の内 容も踏まえた都市計画運用方針，都市計画の広域 調整の方法や同意規準などについて検討を進め, 将来を見据えた都市計画を推進することとしてい る。

\section{おわりに}

まちづくり三法のうち，都市計画法と中心市街 地活性化法が改正されて, 新しいまちづくりが進 められることになるが, 中心市街地の衰退や都市 計画の課題が直ちに解決されるものではない。ま ちづくりはその都市の歴史・文化が積み重なり， その時々の社会情勢の中で多様な変化を示しなが ら醸成され，将来に綿々と受け継がれていくもの である。

県では, 7つの生活圈の各都市の様々な地域特性 を活かして，県民や市町村等との連携のもとに， 都市と田園の共生のあり方を踏まえた, 目指す心゙ き新たな都市像を構築して，その具現化を図るた めの, 将来の都市構造のあり方を検討しながら, 新しい時代に対応できる実効性のある都市計画制 度の実現を図り，「県民誰もが暮らしやすく, 魅力 的で持続可能なまちづくり」を進めていきたいと 考えている。

\section{【参考文献】}
1) 福島県の都市計画
2 ）福島県都市計画年報
3 ) 福島県商業統計
4 ）福島県大規模小売店立地店舗台帳 